\title{
Culture conditions and salt effects on essential oil composition of sweet marjoram (Origanum majorana) from Tunisia
}

\author{
OLFA BAÂTOUR ${ }^{1 *}$ \\ IMEN TARCHOUNE ${ }^{1 *}$ \\ HELA MAHMOUDI ${ }^{1}$ \\ NAWEL NASSRI ${ }^{1}$ \\ WISSAL ABIDI ${ }^{1}$ \\ RYM KADDOUR ${ }^{1}$ \\ GHAITH HAMDAOUI ${ }^{2}$ \\ MOUHIBA BEN NASRI-AYACHI ${ }^{1}$ \\ MOHTAR LACHAẤ ${ }^{1}$ \\ BRAHIM MARZOUK ${ }^{2}$ \\ 1 Unité de Physiologie et Biochimie \\ de la Tolérance au Sel des Plantes \\ Département de Biologie, Faculté \\ des Sciences de Tunis, Campus \\ Universitaire, 2092 Tunis, Tunisie \\ 2 Laboratoire des Substances Bioactives \\ Centre de Biotechnologie de Borj-Cedria \\ BP 901, 2050 Hammam-lif, Tunisie
}

\begin{abstract}
O. majorana shoots were investigated for their essential oil (EO) composition. Two experiments were carried out; the first on hydroponic medium in a culture chamber and the second on inert sand in a greenhouse for 20 days. Plants were cultivated for 17 days in hydroponic medium supplemented with $\mathrm{NaCl} 100 \mathrm{mmol} \mathrm{L}^{-1}$. The results showed that the $O$. majorana hydroponic medium offered higher essential oil yield than that from the greenhouse. The latter increased significantly in yield (by $50 \%$ ) under saline constraint while it did not change in the culture chamber. Under greenhouse conditions and in the absence of salt treatment, the major constituents were terpinen-4-ol and trans-sabinene hydrate. However, in the culture chamber, the major volatile components were cis-sabinene hydrate and terpinen-4-ol. In the presence of $\mathrm{NaCl}$, new compounds appeared, such as eicosane, spathulenol, eugenol, and phenol. In addition, in the greenhouse, with or without salt, a very important change of trans-sabinene hydrate concentration in EO occurred, whereas in the culture chamber change appeared in cis-sabinene hydrate content.
\end{abstract}

Keywords: Origanum majorana, greenhouse, culture chamber, salt, yield, terpinen-4-ol

Sweet marjoram (Origanum majorana L., syn. Majorana hortensis Moench) is a herbaceous and perennial plant native to Cyprus and the Eastern Mediterranean (1). It is an appreciated herb species and its essential oil is also used in perfumery because of its spicy herbaceous notes (2). In addition, essential oil (EO) of O. majorana is utilized in the manufacture of fungicides, and various pharmaceutical and industrial products (2).

Two chemotypes characterize O. majorana essential oil: terpinen-4-ol/sabinene hydrate chemotype (3), and thymol (or carvacrol) chemotype (4). In the first chemotype,

\footnotetext{
*Correspondence; e-mail: baatourolfanaiimi@gmail.com; These authors have equally participated in the preparation of the manuscript.
} 
O. Baâtour et al.: Culture conditions and salt effects on essential oil composition of sweet marjoram (Origanum majorana) from Tunisia, Acta Pharm. 62 (2012) 251-261.

the two major constituents are responsible for the characteristic flavor and fragrance of marjoram oil (5).

In medicinal and aromatic plants, the biosynthesis of secondary metabolites such as essential oils and their constituents is strongly influenced by environmental factors (6). One of the most important environmental constraints that affect almost $50 \%$ of irrigated areas is salinity (7). This constraint generally modifies essential oil biosynthesis and its secretion (8).

The essential oil yield of some species can change with age, growth cycle, climatic conditions, soil type and cropping pattern (9). Culturing conditions can affect the quality of essential oil (10). Moreover, the age of the plant has a significant effect on its essential oil composition (11). However, there is no clear information on the possible influence of culture conditions on essential oil yield and composition in O. majorana. In this paper, we report on combined effects of $\mathrm{NaCl}$ treatment and culturing conditions of Tunisian marjoram aerial parts.

\section{EXPERIMENTAL}

\section{Plant material}

Marjoram (Origanum majorana L., Lamiaceae) plants were collected at the 6-leaf stage from a nursery located in Soliman in northeastern Tunisia (latitude $36^{\circ} 41^{\prime} 47 \mathrm{~N}$; longitude $10^{\circ} 29^{\prime} 30 \mathrm{E}$; altitude $1500 \mathrm{~m}$ ). These 11 days old plants were divided into two lots. The first was used for a hydroponic culture in eight-strength Hoagland's solution (12). Plants were placed in a culture chamber under $16 \mathrm{~h}$ light $/ 8 \mathrm{~h}$ dark conditions at $22 / 18{ }^{\circ} \mathrm{C}$, photosynthetically active radion at $150 \mu \mathrm{mol} \mathrm{m} \mathrm{m}^{-2} \mathrm{~s}^{-1}$. The second lot of plants was transferred to plastic pots ( 1 plant per pot) filled with inert sand. Plants were irrigated with the same nutrient medium and placed in a greenhouse at $35^{\circ} \mathrm{C}$ (day) and $26{ }^{\circ} \mathrm{C}$ (night). After 20 days of acclimatization, individual plants were grown without salt (control) or with $\mathrm{NaCl}\left(100 \mathrm{mmol} \mathrm{L}^{-1}\right)$ for 17 days prior to harvest.

\section{Essential oil isolation}

Essential oil was extracted by classical hydrodistillation of fresh shoots (50 g) during $90 \mathrm{~min}$ according to Msaada et al. (13). The distillate was submitted to a liquid-liquid extraction in diethyl ether and the organic phase was concentrated at $35^{\circ} \mathrm{C}$ using a Vigreux column. In order to quantify EO and its constituents, 6-methyl-5-hepten-2-one was used as an internal standard. Essential oil obtained was stored at $-20{ }^{\circ} \mathrm{C}$ prior to analysis. Each extraction was made in triplicate.

\section{GC-FID}

Gas chromatography analysis was carried out on a Hewlett-Packard 6890 gas chromatograph (Agilent Technologies, USA) equipped with a flame ionization detector (FID) and an electronic pressure control (EPC) injector. A polar column HP Innowax (PEG) and an apolar HP-5 column ( $30 \mathrm{~m} \times 0.25 \mathrm{~mm}, 0.25 \mu \mathrm{m}$ film thickness, Agilent Technologies) 
O. Baâtour et al.: Culture conditions and salt effects on essential oil composition of sweet marjoram (Origanum majorana) from Tunisia, Acta Pharm. 62 (2012) 251-261.

were used. The nitrogen flow rate was $1.6 \mathrm{~mL} \mathrm{~min}^{-1}$ and the split ratio was $60: 1$. EO analysis was performed using the following temperature program: oven $35^{\circ} \mathrm{C}$ for $10 \mathrm{~min}$, from 35 to $205{ }^{\circ} \mathrm{C}$ at a rate of $3{ }^{\circ} \mathrm{C} \mathrm{min}-1$, and isotherm at $225^{\circ} \mathrm{C}$ for $10 \mathrm{~min}$. Injector and detector temperature, were maintained at 250 and $300{ }^{\circ} \mathrm{C}$, respectively.

Retention indices were calculated using a homologous series of $n$-alkanes C6-C20.

\section{GC-MS}

GC-MS analysis was performed on a gas chromatograph HP 5890 (II) interfaced with a HP 5972 mass spectrometer with electron impact ionization $(70 \mathrm{eV})$. A HP-5MS capillary column (apolar, $30 \mathrm{~m} \times 0.25 \mathrm{~mm}, 0.25-\mu \mathrm{m}$ film thickness, Agilent Technologies) was used. Column temperature was programmed to rise from 50 to $240{ }^{\circ} \mathrm{C}$ at a rate of $5{ }^{\circ} \mathrm{C}$ $\mathrm{min}^{-1}$. The carrier gas was helium with a flow rate of $1.2 \mathrm{~mL} \mathrm{~min}^{-1}$; split ratio was 60:1. Scan time and mass range were $1 \mathrm{~s}$ and $40-300 \mathrm{~m} / \mathrm{z}$, respectively.

\section{Statistical analysis}

All extractions and analyses were conducted in triplicate. Data were expressed as means \pm SD.

\section{RESULTS AND DISCUSSION}

\section{Essential oil yield}

Plants growing under different culture conditions did not produce equal yields of $\mathrm{EO}$ and gave rise to different contents and compositions in plant shoots (Table I). Thus, in the culture chamber, the essential oil yield based on dry mass, was $0.8 \%$ in the control, and in the presence of $\mathrm{NaCl}\left(100 \mathrm{mmol} \mathrm{L}^{-1}\right)$. In the greenhouse, $\mathrm{EO}$ decreased by a factor of two in the presence of salt.

In our previous work (14) we showed that Canadian O. majorana can tolerate a moderate $\mathrm{NaCl}$ concentration $\left(50 \mathrm{mmol} \mathrm{L}^{-1}\right)$ without modification in $\mathrm{EO}$ yield and composition. However, at a high $\mathrm{NaCl}$ concentration $\left(100 \mathrm{mmol} \mathrm{L}^{-1}\right)$, significantly modified essential oil yield and quality occured. Similar findings were reported for Salvia hispanica (8). In contrast, salt addition enhanced EO yield in Oenothera biennis (8). In the case of

Table I. Impact of salinity on essential oil yield of marjoram shoots after 2 weeks of treatment

\begin{tabular}{ccc}
\hline & \multicolumn{2}{c}{ Essential oil yield (\%) } \\
\cline { 2 - 3 } & $\mathrm{NaCl}^{\mathrm{a}}\left(100 \mathrm{mmol} \mathrm{L}^{-1}\right)$ & $\mathrm{NaCl}\left(100 \mathrm{mmol} \mathrm{L}^{-1}\right)^{\mathrm{a}}$ \\
\hline Greenhouse & $0.4 \pm 0.1$ & $0.2 \pm 0.0_{3}^{\mathrm{b}}$ \\
Culture chamber & $0.8 \pm 0.0_{4}$ & $0.8 \pm 0.0_{2}{ }^{\mathrm{b}}$ \\
\hline
\end{tabular}

a Mean $\pm \mathrm{SD}, n=3$.

b Significantly different after salt addition at $p<0.05$. 
O. Baâtour et al.: Culture conditions and salt effects on essential oil composition of sweet marjoram (Origanum majorana) from Tunisia, Acta Pharm. 62 (2012) 251-261.

Mathiola tricuspidata, salinity did not exert any effect, on EO yield (8). Diversity of the findings showed that the effect of salt on essential oil yield depends on the salt concentration, culture medium and tolerance of the species.

\section{Culture chamber conditions: essential oil composition of $\mathrm{O}$. majorana shoots}

Gas chromatography analysis of essential oils from the culture chamber showed 44 compounds accounting for $99.86 \%$ of the total EO (Table II), as represented in Figs. 1 c,d. In control plant shoots, the main compound was cis-sabinene hydrate (43.66 \%) followed by terpinen-4-ol (23.21\%), trans-sabinene hydrate $(8.17 \%)$ and $\alpha$-humulene $(7.30 \%)$. Salt addition induced a decrease estimated at $4.40 \%$ for cis-sabinene hydrate, $5.66 \%$ terpinen-4-ol, $4.83 \%$ trans-sabinene hydrate and $2.89 \% \alpha$-humulene as compared to the control. In that case, EO was of cis-sabinene hydrate/terpinen-4-ol chemotype, which is responsible for the characteristic flavor and fragrance of marjoram.

Our results are in accord with those of Bronchio et al. (3). Our previous data (14) showed that the essential oil of Canadian Origanum cultivated under the same conditions as the Tunisian one was found to be rich in trans-sabinene hydrate $(47.67 \%)$, and terpinen-4-ol (20.82\%).

Salinity had a significant effect $(p<0.05)$ on the composition and content of the major EO. In the culture camber cis-sabinene hydrate and terpinen-4-ol proportions were decreased, while their concentrations increased. In fact, $\mathrm{NaCl}\left(100 \mathrm{mmol} \mathrm{L}^{-1}\right)$ increased cis-sabinene hydrate and terpinen-4-ol contents significantly (125 times to reach $20.60 \mathrm{mg} \mathrm{g}^{-1}$ and 6 times to reach $0.556 \mathrm{mg} \mathrm{g}^{-1}$ ) respectively. Despite these changes, O. majorana retained the same chemotype after salt addition.

In the culture chamber, an important bioconversion of EO composition of O. majorana shoots from trans-sabinene hydrate into cis-sabinene hydrate was detected (Table II). These two isomers are biosynthesized by the same enzyme, sabinene hydrate synthase (1). In fact, these culture conditions activate this enzyme, favouring the biosynthesis of cis-sabinene hydrate. Indeed, this is an intensive and spic component of marjoram, whereas the trans-sabinene hydrate does not have any typical properties of marjoram (1).

Essential oil composition of shoots was characterized by the prevalence of terpenic alcohols in a proportion of $86.20 \%$, standing for cis-sabinene hydrate, trans-sabinene hydrate, and terpinen-4-ol, and $8.48 \%$ for monoterpene hydrocarbons (Table II). In the same context, Baatour et al. (14) indicated that the most represented class of EO components of O. majorana native to Canada was that of oxygenated monoterpenes, followed by monoterpene hydrocarbons and esters in control plants. A decrease in these different compound proportions was observed after salt addition, except for monoterpene hydrocarbons and phenols.

\section{Greenhouse conditions: Essential oil composition O. majorana shoots}

Thirty-two compounds were found to represent $99.55 \%$ of EO (Table III), as shown in Figs. 1 a,b. Independent of the applied treatment, terpinen-4-ol was detected as the major compound $(31.77 \%)$, followed by trans-sabinene hydrate $(24.18 \%)$ and $\alpha$-ter- 
O. Baâtour et al.: Culture conditions and salt effects on essential oil composition of sweet marjoram (Origanum majorana) from Tunisia, Acta Pharm. 62 (2012) 251-261.
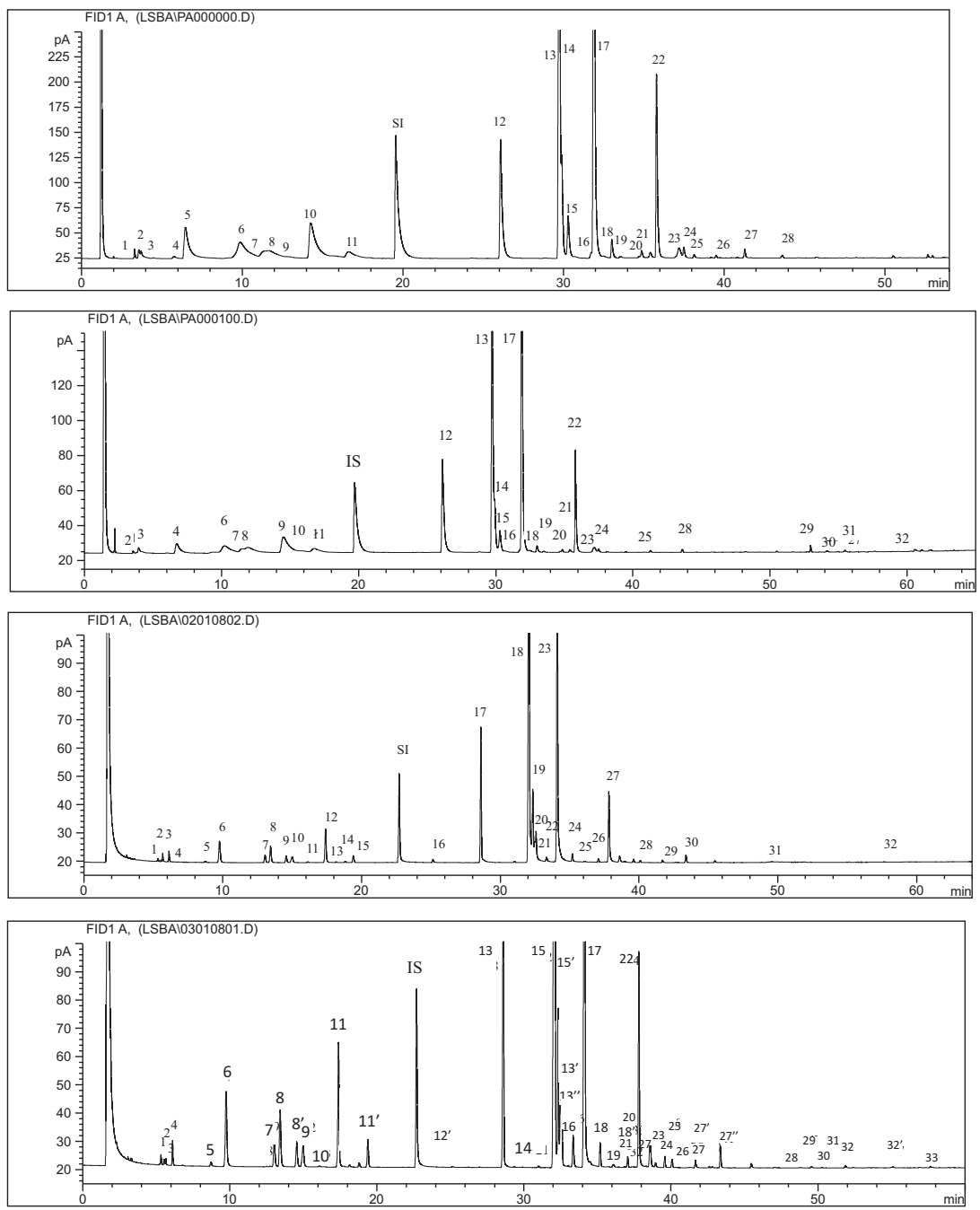

Fig. 1. Chromatogram of essential oil compounds from Origanum majorana.

a) $100 \mathrm{mmol} \mathrm{L}^{-1} \mathrm{NaCl}$ in the greenhouse after 17 days of treatment; b) $100 \mathrm{mmol} \mathrm{L}-1 \mathrm{NaCl}^{\text {in the }}$ greenhouse, after 17 days of treatment; c) $100 \mathrm{mmol} \mathrm{L}^{-1} \mathrm{NaCl}$, in the culture chamber, after 17 days of treatment; d) $75 \mathrm{mmol} \mathrm{L}-1 \mathrm{NaCl}$, in the culture chamber, after 17 days of treatment.

SI: internal standard (6-methyl 5 heptene 2 one). 1: Tricyclene, 2: $\alpha$-pinene; $3: \alpha$-tujene; 4 : sabinene; 5: $\beta$-myrcene; 6: $\alpha$-phellandrene; 7: $\alpha$-terpinene; 8: limonene; 8': 1,8-cineole; 9: $\gamma$-terpinene; 10: $p$-cymene; 11: terpinolene; 11': octanol; 12: cis-3-hexanol; 12': hexanol; 13: trans-sabinene hydrate; 13': linalyl acetate; $13^{\prime \prime}$ : bornyl acetate; 14 : linalool, 15 : cis-sabinene hydrate; $15^{\prime}$ : cis-p-menth-en-1-ol; 16 : $\beta$-elemene, 17: terpinen-4-ol, 18: $\beta$-caryophyllene, 18': $\alpha$-humulene; 19: aromadendrene; 20: bicyclogermacrene; 21: $\alpha$-terpenyl acetate; 22: $\alpha$-terpineol; 23: borneol; 24: neryl acetate, 25: geranyl acetate, 26: nerol, 27: myrthenol; 27': geraniol; 27": cis-caveol; 28: nonadecane; 29: eiocasane; 30: spathuneol; 31: eugenol; 32: phenol; 32': thymol; 33: carvacrol. 
O. Baâtour et al.: Culture conditions and salt effects on essential oil composition of sweet marjoram (Origanum majorana) from Tunisia, Acta Pharm. 62 (2012) 251-261.

Table II. Essential oil composition of Origanum majorana in the culture chamber by GC-MS

\begin{tabular}{|c|c|c|c|c|c|c|c|}
\hline \multirow[b]{3}{*}{ Compound } & \multicolumn{7}{|c|}{$\mathrm{NaCl}$} \\
\hline & & & & $\begin{array}{c}0 \\
\left(\mathrm{mmol} \mathrm{L}^{-1}\right)\end{array}$ & $\begin{array}{c}100 \\
\left(\mathrm{mmol} \mathrm{L}^{-1}\right)\end{array}$ & $\begin{array}{c}0 \\
\left(\mathrm{mmol} \mathrm{L}{ }^{-1}\right)\end{array}$ & $\begin{array}{c}100 \\
\left(\mathrm{mmol} \mathrm{L}^{-1}\right)\end{array}$ \\
\hline & $t_{\mathrm{R}}(\min )$ & $\mathrm{KI}^{\mathrm{a}}$ & $\mathrm{KI}^{\mathrm{b}}$ & $(\%)^{\mathrm{C}}$ & $(\%)^{\mathrm{C}}$ & $\left(\mathrm{mg} \mathrm{g}^{-1}\right)^{\mathrm{c}, \mathrm{d}}$ & $\left(m g g^{-1}\right)^{c, d}$ \\
\hline Tricyclene & 5.32 & 927 & 1014 & 0.142 & 0.193 & 0.045 & $0.409^{\mathrm{e}}$ \\
\hline$\alpha$-Pinene & 5.54 & 931 & 1035 & 0.07 & $0.106^{\mathrm{e}}$ & 0.532 & $0.011^{\mathrm{e}}$ \\
\hline$\alpha$-Thujene & 5.66 & 939 & 1032 & 0.339 & $0.106^{\mathrm{e}}$ & 0.265 & $0.021^{\mathrm{e}}$ \\
\hline Sabinene & 6.11 & 976 & 1132 & 0.094 & $0.134^{\mathrm{e}}$ & 0.352 & $0.290^{\mathrm{e}}$ \\
\hline$\beta$-myrcene & 8.74 & 991 & 1174 & ND & 0.016 & ND & 0.138 \\
\hline$\alpha$-Phellandrene & 9.7 & 1006 & 1176 & 0.562 & $0.787^{\mathrm{e}}$ & 2.106 & $1.041^{\mathrm{e}}$ \\
\hline$\alpha$-Terpinene & 13.04 & 1016 & 1188 & 1.292 & $1.730^{\mathrm{e}}$ & 4.839 & $0.046^{\mathrm{e}}$ \\
\hline Limonene & 13.43 & 1030 & 1203 & 0.517 & $0.742^{\mathrm{e}}$ & 1.937 & $0.091^{\mathrm{e}}$ \\
\hline 1.8-Cineole & 14.56 & 1033 & 1213 & 0.582 & $0.782^{\mathrm{e}}$ & 2.179 & $0.022^{\mathrm{e}}$ \\
\hline$\gamma$-Terpinene & 14.99 & 1062 & 1266 & 0.062 & $0.030^{\mathrm{e}}$ & 0.235 & $0.843^{\mathrm{e}}$ \\
\hline$p$-Cymene & 16.12 & 1026 & 1280 & 0.050 & 0.054 & 0.187 & $0.334^{\mathrm{e}}$ \\
\hline Terpinolene & 17.33 & 1088 & 1290 & 0.069 & $0.107^{\mathrm{e}}$ & 0.261 & $0.042^{\mathrm{e}}$ \\
\hline Octanal & 19.39 & - & - & 0.474 & $0.725^{\mathrm{e}}$ & 1.777 & $0.144^{\mathrm{e}}$ \\
\hline Hexanol & 25.12 & - & - & 0.210 & $0.020^{\mathrm{e}}$ & 0.789 & $0.592^{\mathrm{e}}$ \\
\hline cis-3-Hexanol & 26.95 & - & 1385 & ND & 0.010 & ND & 0.010 \\
\hline trans-Sabinene hydrate & 29.74 & 1053 & 1474 & 8.178 & $7.783^{\mathrm{e}}$ & 0.030 & $1.600^{\mathrm{e}}$ \\
\hline Linalool & 29.89 & 1098 & 1553 & ND & 0.043 & 0.289 & $0.084^{\mathrm{e}}$ \\
\hline cis-Sabinene hydrate & 32.06 & 1082 & 1556 & 43.667 & $41.745^{\mathrm{e}}$ & 0.163 & $20.595^{\mathrm{e}}$ \\
\hline cis-p-Menthen-1-ol & 32.34 & 1129 & 1562 & 4.892 & $3.544^{e}$ & 0.018 & $1.808^{\mathrm{e}}$ \\
\hline Linalyl acetate & 32.49 & 1257 & 1556 & 0.993 & $1.472^{\mathrm{e}}$ & 3.720 & $8.845^{\mathrm{e}}$ \\
\hline Bornyl acetate & 32.58 & 1295 & 1597 & 2.272 & $1.974^{\mathrm{e}}$ & 8.507 & $8.845^{\mathrm{e}}$ \\
\hline$\beta$-Elemene & 33.33 & 1391 & 1601 & 0.329 & $0.837^{\mathrm{e}}$ & 1.234 & $0.289^{e}$ \\
\hline Terpinene-4-ol & 34.11 & 1176 & 1611 & 23.209 & $21.894^{\mathrm{e}}$ & 0.086 & $0.556^{\mathrm{e}}$ \\
\hline B-Caryophyllene & 35.19 & 1419 & 1612 & 0.450 & $0.507^{\mathrm{e}}$ & 1.688 & $58.240^{\mathrm{e}}$ \\
\hline Aromadendrene & 36.07 & 1443 & 1628 & ND & 0.0169 & ND & 3.834 \\
\hline$\alpha$-Humulene & 36.85 & 1454 & 1687 & 7.300 & $7.089^{\mathrm{e}}$ & 1.301 & $1.160^{\mathrm{e}}$ \\
\hline Bicyclogermacrene & 37.06 & 1344 & 1705 & 0.199 & $0.227 \mathrm{e}$ & 0.746 & $0.285^{\mathrm{e}}$ \\
\hline$\alpha$-Terpenyl acetate & 37.43 & 1494 & 1755 & ND & 0.021 & ND & 2.049 \\
\hline Myrtenyl acetate & 37.43 & 1335 & 1701 & ND & 0.021 & ND & 2.049 \\
\hline$\alpha$-Terpineol & 40.08 & 1189 & 1713 & 4.619 & $4.995^{\mathrm{e}}$ & 0.017 & $9.820^{\mathrm{e}}$ \\
\hline Borneol & 39.60 & 1165 & 1702 & 0.203 & $0.241^{\mathrm{e}}$ & 0.763 & $41.500^{\mathrm{e}}$ \\
\hline Neryl acetate & 40.08 & 1385 & 1733 & 0.133 & $0.193^{\mathrm{e}}$ & 0.499 & $1.740^{\mathrm{e}}$ \\
\hline Geranyl acetate & 40.35 & 1383 & 1765 & $\mathrm{ND}$ & 0.007 & $\mathrm{ND}$ & 0.811 \\
\hline Nerol & 41.68 & 1228 & 1797 & 0.170 & $0.161^{\mathrm{e}}$ & 0.638 & $0.468^{\mathrm{e}}$ \\
\hline
\end{tabular}


O. Baâtour et al.: Culture conditions and salt effects on essential oil composition of sweet marjoram (Origanum majorana) from Tunisia, Acta Pharm. 62 (2012) 251-261.

Table II. continued

\begin{tabular}{|c|c|c|c|c|c|c|c|}
\hline Myrtenol & 42.61 & 1194 & 1804 & 0.027 & $0.024^{\mathrm{e}}$ & 0.104 & $3.253^{\mathrm{e}}$ \\
\hline Geraniol & 42.80 & 1255 & 1857 & ND & 0.025 & ND & 0.021 \\
\hline cis-Caveol & 43.37 & 1247 & 1804 & 0.449 & $0.462^{\mathrm{e}}$ & 1.683 & $0.392^{\mathrm{e}}$ \\
\hline Nonadecane & 48.81 & 1581 & 1900 & ND & 0.011 & ND & 0.010 \\
\hline Eicosane & 49.56 & 1996 & 2000 & 0.036 & $0.034^{\mathrm{e}}$ & 0.138 & $0.065^{\mathrm{e}}$ \\
\hline Spathulenol & 50.26 & - & 2144 & ND & 0.012 & ND & 0.008 \\
\hline Phenol & 51.85 & - & - & ND & 0.056 & ND & 0.093 \\
\hline Eugenol & 52.40 & 1401 & 2030 & ND & 0.013 & ND & 5.186 \\
\hline Thymol & 55.08 & 1295 & - & ND & 0.041 & ND & 0.063 \\
\hline Carvacrol & 57.65 & 1302 & - & 0.025 & $0.045^{\mathrm{e}}$ & 0.096 & $0.023^{e}$ \\
\hline \multicolumn{8}{|c|}{ Classes } \\
\hline \multicolumn{4}{|c|}{ Monoterpene hydrocarbons } & 8.483 & $11.126^{\mathrm{e}}$ & 31.766 & $4.744^{\mathrm{e}}$ \\
\hline \multicolumn{4}{|c|}{ Terpenic alcohols } & 86.207 & $81.671^{\mathrm{e}}$ & 320.141 & $48.012^{\mathrm{e}}$ \\
\hline \multicolumn{4}{|c|}{ Sesquiterpene hydrocarbons } & 0.714 & $0.156^{\mathrm{e}}$ & 2.675 & $0.162^{\mathrm{e}}$ \\
\hline \multicolumn{4}{|c|}{ Terpenic esters } & 3.265 & $3.306^{\mathrm{e}}$ & 12.228 & $0.048^{\mathrm{e}}$ \\
\hline \multicolumn{4}{|c|}{ Aliphatic hydrocarbons } & 0.003 & $0.004^{\mathrm{e}}$ & 0.138 & $0.076^{\mathrm{e}}$ \\
\hline \multicolumn{4}{|c|}{ Phenols } & 0.025 & $0.156^{\mathrm{e}}$ & 0.964 & $0.193^{e}$ \\
\hline
\end{tabular}

$t_{\mathrm{R}}$ - retention time, KI - Kovat's index on: ${ }^{\mathrm{a}}$ apolar column HP-5MS, ${ }^{\mathrm{b}}$ polar column HP-Innowax (relative to $n$-alkane), ND - not detected.

${ }^{c}$ Mean of 3 replicates.

d Dry mass basis.

e Significantly different after salt addition at $p<0.05$.

pineol $(7.30 \%)$. In the presence of $\mathrm{NaCl}\left(100 \mathrm{mmol} \mathrm{L}^{-1}\right)$, a small increase was observed in terpinen-4-ol percentage, while percentages of trans-sabinene hydrate and $\alpha$-terpineol were not affected.

In the absence or presence of salt, O. majorana EO was of trans-sabinene hydrate/ terpinen-4-ol chemotype. These results are in agreement with those of Hamrouni et al. (9), who reported that the major constituents were terpinen-4-ol, cis-sabinene hydrate, and trans-sabinene hydrate. Later investigations showed that some of the above main constituents were found in numerous EO samples of O. majorana. Novak et al. (1) mentioned that the main compounds of marjoram EO were the epimeric monoterpene alcohols, trans-sabinene hydrate, cis-sabinene hydrate, and cis-sabinene hydrate acetate. In fact, according to Vera and Chane-Ming (2), the main components were terpinen-4-ol and cis-sabinene hydrate in EO of O. majorana originating from Island.

Our results showed that $\mathrm{NaCl}$ modified the essential oil composition. In fact, new compounds appeared: eicosane, spathulenol, eugenol, and phenol (Table III). However, myrcene, present in the control, disappeared under saline conditions.

Indeed, a very important modification of EO composition was bioconversion from cis-sabinene hydrate into trans-sabinene hydrate. Culture conditions had an important effect on the transformation of these two isomers: from cis- to trans-sabinene hydrate under greenhouse conditions and from trans- to cis-sabinene hydrate under culture cham- 
O. Baâtour et al:: Culture conditions and salt effects on essential oil composition of sweet marjoram (Origanum majorana) from Tunisia, Acta Pharm. 62 (2012) 251-261.

ber conditions. These results suggest that culture conditions activated sabinene hydrate synthase in favor of cis-sabinene hydrate or trans-sabinene hydrate.

Under saline conditions, contents of all compounds evolved in the same way (Table III). The composition of EO of O. majorana shoots is primarily made up of terpenic alcohols $(78.27 \%)$, followed by monoterpene hydrocarbons in the control (18.74\%). Salinity decreased the content of each class, except for aliphatic hydrocarbons and terpenic alcohols (Table III).

The quality of the EO produced and its composition in Origanum majorana depends on culturing conditions (15). Our findings are in accord with those of Avry and Gallouin (9) and Kotan et al. (16). Essential oil of O. majorana plants cultivated in a greenhouse had lower level of flavor than EO of plants cultivated in the culture chamber due to the great difference in the cis-sabinene hydrate production. Therefore marjoram cultivated

Table III. Essential oil composition of Origanum majorana in the greenhouse by GC-MS.

\begin{tabular}{|c|c|c|c|c|c|c|c|}
\hline \multirow[b]{3}{*}{ Compound } & \multicolumn{7}{|c|}{$\mathrm{NaCl}\left(\mathrm{mmol} \mathrm{L}^{-1}\right)$} \\
\hline & & & & 0 & 100 & 0 & 100 \\
\hline & $t_{\mathrm{R}}(\min )$ & $\mathrm{RI}^{\mathrm{a}}$ & $\mathrm{RI}^{\mathrm{b}}$ & $(\%)^{\mathrm{C}}$ & $(\%)^{\mathrm{c}}$ & $\left(\mathrm{mg} \mathrm{g}^{-1}\right)^{\mathrm{c}, \mathrm{d}}$ & $\left(\mathrm{mg} \mathrm{g}^{-1}\right)^{\mathrm{c}, \mathrm{d}}$ \\
\hline Tricyclene & 3.28 & - & - & 0.252 & ND & 0.045 & ND \\
\hline$\alpha$-Pinene & 3.55 & 931 & 1035 & 0.316 & $0.121^{\mathrm{e}}$ & 0.056 & $0.019^{e}$ \\
\hline$\alpha$-Thujene & 3.69 & 939 & 1032 & 0.506 & $0.430^{\mathrm{e}}$ & 0.090 & $0.070^{\mathrm{e}}$ \\
\hline Sabinene & 5.74 & 976 & 1132 & 0.181 & $2.067^{\mathrm{e}}$ & 0.032 & $0.338^{\mathrm{e}}$ \\
\hline$\beta$-Myrcene & 6.45 & 991 & 1174 & 3.807 & ND & 0.678 & ND \\
\hline$\alpha$-Phellandrene & 9.84 & 1006 & 1176 & 4.145 & $3.602^{\mathrm{e}}$ & 0.738 & $0.589^{\mathrm{e}}$ \\
\hline$\alpha$-Terpinene & 11.39 & 1016 & 1188 & 0.710 & $0.724^{\mathrm{e}}$ & 0.126 & $0.118^{\mathrm{e}}$ \\
\hline Limonene & 11.49 & 1030 & 1203 & 0.162 & $2.205^{\mathrm{e}}$ & 0.028 & $0.361^{\mathrm{e}}$ \\
\hline$\gamma$-Terpinene & 11.61 & 1033 & 1213 & 1.448 & $1.903^{\mathrm{e}}$ & 0.258 & $0.311^{\mathrm{e}}$ \\
\hline p-Cymene & 14.25 & 1062 & 1266 & 5.883 & $3.215^{\mathrm{e}}$ & 1.048 & $0.526^{\mathrm{e}}$ \\
\hline Terpinolene & 16.62 & 1026 & 1280 & 1.183 & $1.081^{\mathrm{e}}$ & 0.210 & $0.176^{\mathrm{e}}$ \\
\hline cis-3-Hexanol & 26.62 & 1088 & 1290 & 7.428 & $10.650^{\mathrm{e}}$ & 1.323 & $1.743^{\mathrm{e}}$ \\
\hline trans-Sabinene hydrate & 29.74 & 1053 & 1474 & 24.181 & $24.541^{\mathrm{e}}$ & 4.309 & 4.017 \\
\hline Linalool & 29.89 & 1098 & 1553 & 3.994 & $3.724^{\mathrm{e}}$ & 0.711 & $0.609 \mathrm{e}$ \\
\hline cis-Sabinene hydrate & 30.283 & 1082 & 1556 & 2.235 & $2.492^{\mathrm{e}}$ & 0.398 & $0.408^{\mathrm{e}}$ \\
\hline$\beta$-Elemene & 31.729 & 1053 & 1474 & 0.197 & $0.225^{\mathrm{e}}$ & 0.035 & 0.036 \\
\hline Terpinen-4-ol & 31.91 & 1098 & 1553 & 31.77 & $29.050^{\mathrm{e}}$ & 5.662 & $4.756^{\mathrm{e}}$ \\
\hline$\beta$-Caryophyllene & 32.47 & 1082 & 1556 & 0.210 & $0.311^{\mathrm{e}}$ & 0.037 & $0.051^{\mathrm{e}}$ \\
\hline Aromadendrene & 33.00 & 1129 & 1562 & 0.864 & $0.545^{\mathrm{e}}$ & 0.154 & $0.089^{\mathrm{e}}$ \\
\hline Bicyclogermacrene & 34.86 & 1257 & 1556 & 0.335 & $0.223^{e}$ & 0.059 & $0.036^{\mathrm{e}}$ \\
\hline$\alpha$-Terpenyl acetate & 35.40 & 1295 & 1597 & 0.320 & $0.238^{\mathrm{e}}$ & 0.057 & $0.039^{\mathrm{e}}$ \\
\hline$\alpha$-Terpineol & 35.78 & 1391 & 1601 & 7.300 & $7.089 \mathrm{e}$ & 1.301 & $1.160^{\mathrm{e}}$ \\
\hline
\end{tabular}


O. Baâtour et al.: Culture conditions and salt effects on essential oil composition of sweet marjoram (Origanum majorana) from Tunisia, Acta Pharm. 62 (2012) 251-261.

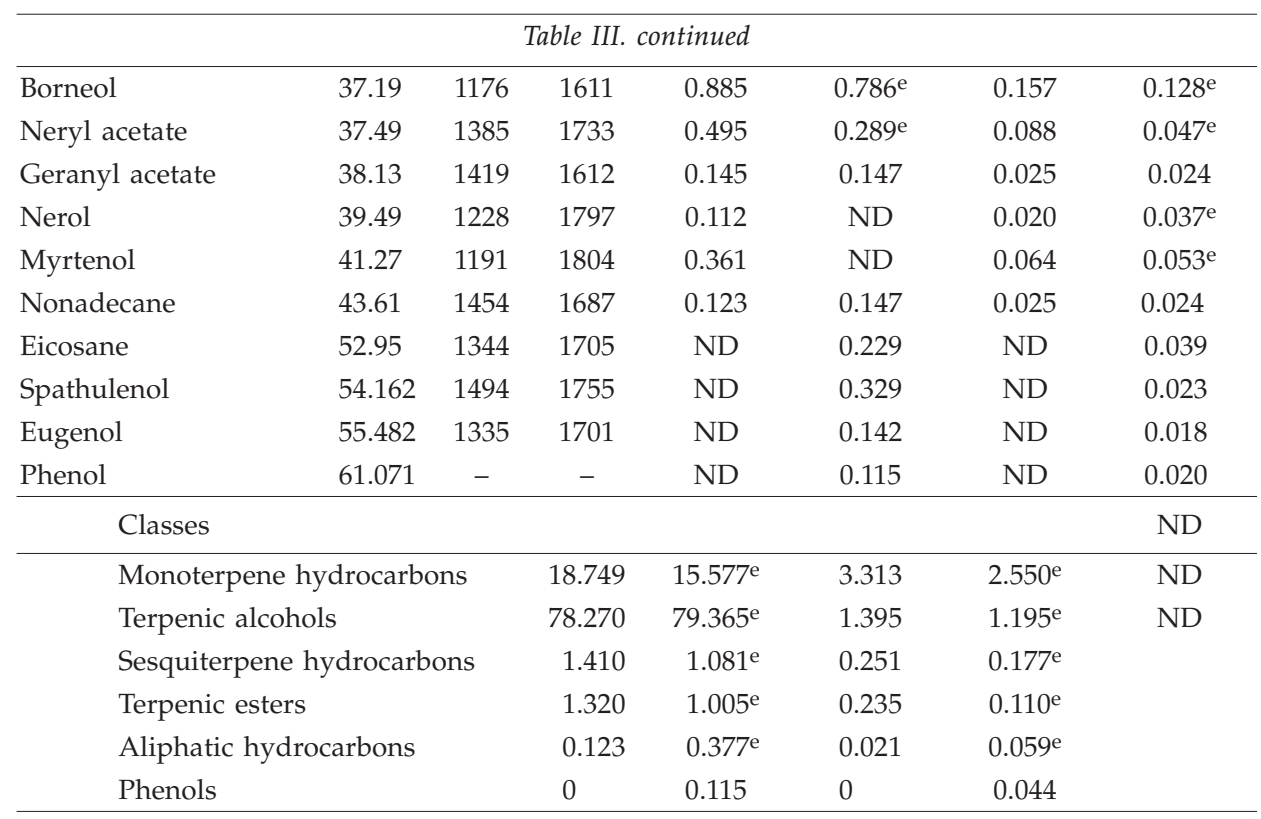

$t_{R}$ - Retention time.

KI - Kovat's index on: a apolar column HP-5MS, b polar column HP-Innowax (relative to $n$-alkane). ND - not detected.

${ }^{\mathrm{c}}$ Mean of 3 replicates.

${ }^{\mathrm{d}}$ Drug mass basis.

e Significantly, different after salt addition at $p<0.05$.

in the greenhouse was of higher quality than that cultivated in the culture chamber because of its high terpinen-4-ol concentration (Tables II, III). The EO is believed to have had medicinal properties because of the presence of biologically active compounds such as terpinen-4-ol (5). In fact, terpinen-4-ol, $\alpha$-terpineol, and linalool exhibited high antibacterial activity. O. majorana EO is known for its strong antimicrobial activity and could therefore be used in food applications.

\section{CONCLUSIONS}

Our data indicate high variations in quantitative and qualitative composition of $O$. majorana EOs produced under two conditions: greenhouse and culture chamber. The study showed that EO yield and composition depend on the culturing and climatic conditions. We observed an important modification in EO composition of O. majorana shoots by converting trans-sabinene hydrate into cis-sabinene hydrate in the culture chamber and cis- to trans-sabinene hydrate in the greenhouse. The EO of the latter was considered to be of higher quality than that cultivated in the culture chamber, because of its higher concentration of oxygenated compounds, particularly bioactive compounds such as terpinen-4-ol. 


\section{REFERENCES}

1. J. Novak, C. Bitsch, J. Langbehn, F. Pank, M. Skoula and Y. Gotsiou, Ratios of cis and trans-sabinene hydrate in Origanum majorana L. and Origanum microphyllum (Bentham) Vogel, Biochem. Syst. Ecol. 28 (2000) 697-704; DOI: org/10.1016/S0305-1978(99)00098-8.

2. R. R. Vera and J. Chane-Ming, Chemical composition of the essential oil of marjoram (Origanum majorana L.) from Reunion Island, Food Chem. 66 (1999) 143-145; DOI: org/10.1016/S0308-8146 (98)00018-1.

3. E. Banchio, P. C Bogino, J. Zygadlo and W. Giordano, Plant growth promoting rhizobacteria improve growth and essential oil yield in Origanum majorana L., Biochem. Syst. Ecol. 36 (2008) 66-771; DOI: $10.1016 /$ j.bse.2008.08.006.

4. K. H. C Baser, N. Kirimer and G. Tümen, Composition of the essential oil of Origanum majorana L. from Turkey, J. Essent. Oil Res. 5 (1993) 577-579; DOI: 10.1080/10412905.1993.9698283.

5. E. V. Vági, B. Simándi, Á. Suhajda and É. Héthelyi, Essential oil composition and antimicrobial activity of Origanum majorana L. extracts obtained with ethyl alcohol and supercritical carbon dioxide, Food Res. Int. 38 (2005) 51-57; DOI: 10.1061/j.foodres.2004.07.006.

6. G. W. Stutte, Process and product: recirculation hydroponics and bioactive compounds in a controlled environment, Hort. Sci. 41 (2006) 526-530.

7. Z. Flagella, V. Cantore, M. M. Giuliani, E. Tarantino and A. De Caro, Crop salt tolerance. Physiological, yield and quality aspects, Rec. Res. Dev. Plant Biol. 2 (2002) 155-186.

8. B. Heuer, Z. Yaniv and I. Ravina, Effect of late salinization of chia (Salvia hispanica), stock (Matthiola tricuspidata) and evening primrose (Oenothera biennis) on their oil content and quality, Ind. Crop Prod. 5 (2002) 163-167; DOI: 10.1016/S0926-6690(01)00107-8.

9. S. I. Hamrouni, E. Maamouri, T. Chahed, W. W Aidi, M. E. Kchouk and B. Marzouk, Effect of growth stage on the content and composition of the essential oil and phenolic fraction of sweet marjoram (Origanum majorana L.), Ind. Crop Prod. 30 (2009) 395-402; DOI: 10.1016/j.indcrop. 2009. 07.010.

10. A. M. Viljoen, S. Subramoney, S. F. van Vuuren, K. H. C. Baser and T. B. Demirci, The composition, geographical variation and antimicrobial activity of Lippia javanica (Verbenaceae) leaf essential oils, J. Ethnopharmacol. 96 (2005) 271-277; DOI: 10.1016/j.jep.2004.09.017.

11. H. Bayder and N. G. Bayder, The effects of harvest date, fermentation duration and Tween 20 treatment on essential oil content and composition of industrial oil rose (Rosa damascena Mill.), Ind. Crop Prod. 21 (2005) 251-255; DOI: 10.1016/j.indcrop.2004.04.004.

12. D. R. Hoagland and D. I. Arnon, The water-culture method for growing plants without soil, $\mathrm{Ca}-$ lif. Agric. Exp. Cir. 347 (1950) 1-32.

13. K. Msaada, K. Hosni, M. Ben Taarit, T. Chahed, M. E. Kchouk and B. Marzouk Changes on essential oil composition of coriander (Coriandrum sativum L.) fruits during three stages of maturity, Food. Chem. 102 (2007) 1131-1134; DOI: 10.1016/j.foodchem.2006.06.046.

14. O. Baâtour, R. Kaddour, W. Aidi, M. Laachâl and B. Marzouk, Salt effects on the growth, mineral nutrition, essential oil yield and composition of marjoram (Origanum majorana), Acta Physiol. Plant. 32 (2010) 45-51; DOI 10.1007/s11738-009-0374-4.

15. R. Kotan, S. Kordalic and A. Cakird, Screening of antibacterial activities of twenty one oxygenated monoterpenes, Z. Naturforsch. 62 (2007) 507-513.

16. I. Telci, I. Demirtas, E. Bayram, O. Arabacid and O. Kacare, Environmental variation on aroma components of pulegone/piperitone rich spearmint (Mentha spicata L.), Ind. Crop Prod. 32 (2010) 588-592; DOI: 10.1016/j.indcrop.2010.07.009. 
O. Baâtour et al.: Culture conditions and salt effects on essential oil composition of sweet marjoram (Origanum majorana) from Tunisia, Acta Pharm. 62 (2012) 251-261.

$S A \check{Z} E T A K$

\section{Utjecaj uvjeta uzgoja i dodatka soli na sastav eteričnog ulja slatkog mažurana (Origanum majorana) iz Tunisa}

OLFA BAÂTOUR, IMEN TARCHOUNE, HELA MAHMOUDI, NAWEL NASSRI, WISSAL ABIDI, RYM KADDOUR, GHAITH HAMDAOUI, MOUHIBA BEN NASRI-AYACHI, MOHTAR LACHAÂL i BRAHIM MARZOUK

U radu je opisano ispitivanje sastava eteričnog ulja izdanaka biljke O. majorana. Provedena su dva eksperimenta: prvi na hidroponom mediju u komorama za uzgoj, a drugi na inertnom pijesku u stakleniku tijekom 20 dana. Biljke su uzgajane 17 dana u hidroponom mediju u koji je dodan $\mathrm{NaCl} 100 \mathrm{mmol} \mathrm{L}^{-1}$. Rezultati ukazuju na to da hidroponi medij O. majorana osigurava veće prinose eteričnog ulja nego staklenik. U stakleniku se prinos ulja značajno povećao dodavanjem 50 \% soli dok u uzgoju u uzgojnoj komori nije bilo promjene. U uvjetima u stakleniku i u odsutnosti soli, najvažniji sastojci ulja bili su terpinen-4-ol i trans-sabinen hidrat, dok su u uvjetima uzgojne komore najvažnije hlapljive komponente bile cis-sabinen hidrat i terpinen-4-ol. U prisutnosti $\mathrm{NaCl}-\mathrm{a}$, pojavili su se novi sastojci, kao što su eikozan, spatulenol, eugenol i fenol. Dodatno je uz stakleničke uvjete, sa i bez soli, došlo do važne promjene u količini trans-sabinen hidrata u eteričnom ulju, dok se u komorama promijenio sadržaj cis-sabinen hidrata.

Ključne riječi: Origanum majorana, staklenik, uzgojna komora, sol, prinos, terpinen-4-ol

Unité de Physiologie et Biochimie de la Tolérance au Sel des Plantes, Département de Biologie, Faculté des Sciences de Tunis, Campus Universitaire, 2092 Tunis, Tunisie

Laboratoire des Substances Bioactives, Centre de Biotechnologie de Borj-Cedria, BP 901, 2050

Hammam-lif, Tunisie 